\title{
TERGANGGUNYA PERKEMBANGAN KOGNITIF BERPENGARUH TERHADAP KREATIVITAS SISWA XKKBT TAHUN AJARAN 2020/2021 DENGAN UJI KOLMOGOROV SMIRNOV
}

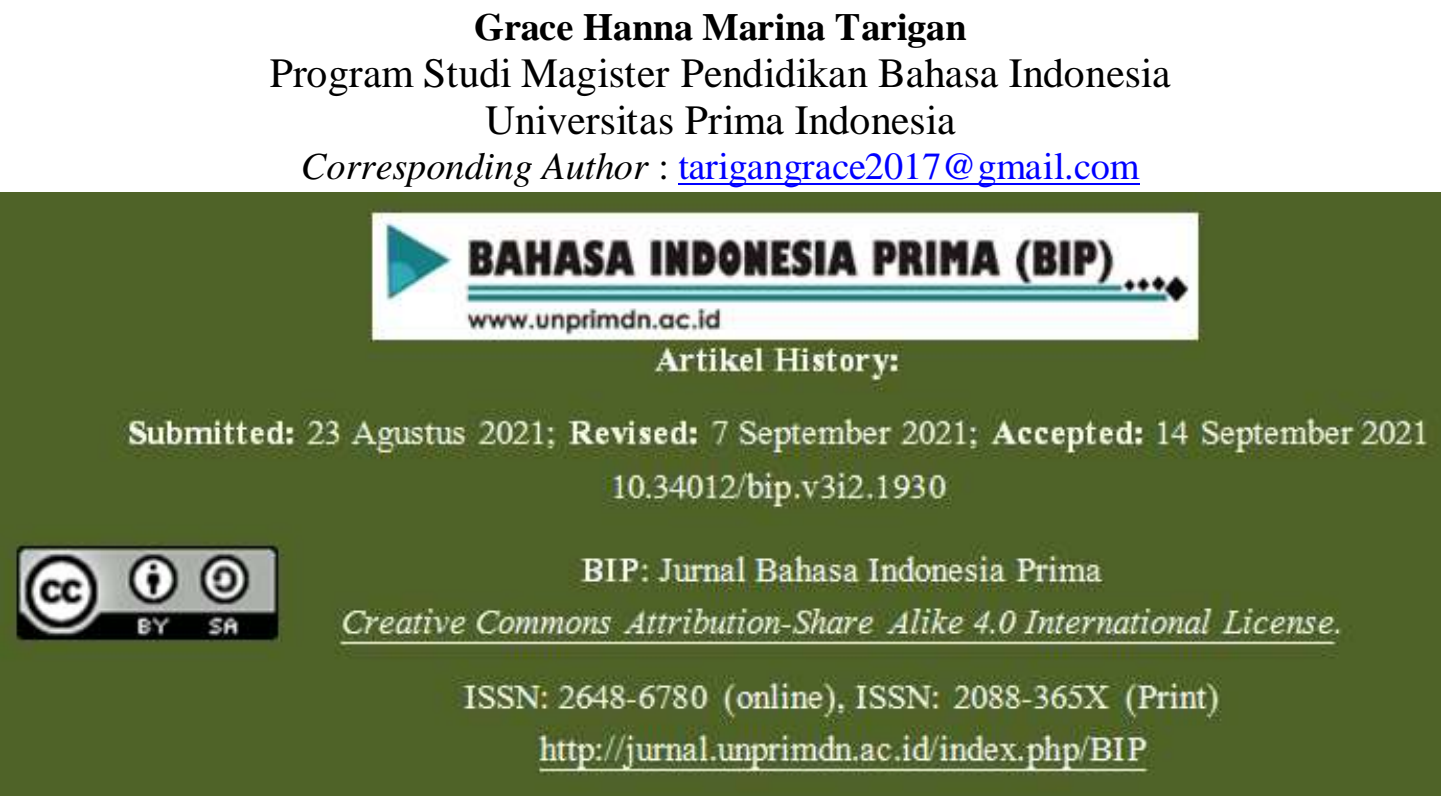

Abstrak-Kreativitas digambarkan jika seseorang menghasilkan komposisi, produk, gagasan apa saja yang pada dasarnya baru. Gangguan kognitif yang mempengaruhi fungsi intelektual, mengganggu kesadaran dan dapat menyebabkan kesulitan dalam belajar. Pada tulisan ini , peneliti menggunakan Uji Kolmogorov Smirnov.

Kata kunci: kognitif, kreativitas, uji kolmogorov

\section{A. Pendahuluan}

Potensi kognitif ditentukan pada masa-masa konsepsi yaitu pertemuan antara sel sperma dan sel telur, apakah akan menjadi sesuatu potensi kognitif dan tergantung juga dari lingkungan dan kesempatan yang diberikan.

Faktor keturunan juga sangat tergantung pada potensi kognitif dan sangat menentukan batas perkembangan tingkat inteligiensi (batas maksimal). Kognisi itu sendiri merupakan suatu proses berpikir dimana kemampuan individu untuk menghubungkan menilai dan mempertimbangkan suatu kejadian atau peristiwa. Kemampuan inteligiensi sangat menentukan cepat atau tidak suatu masalah cepat terselesaikan.Kecerdasan merupakan kemampuan mental tertinggi yang dimiliki oleh manusia.Tingkat kecerdasan dapat membantu seseorang dalam menghadapi permasalahan yang muncul dalam kehidupan. Pamela Minet mendefenisikan perkembangan intelektual sama dengan perkembangan mental, sedangkan perkembangan kognitif adalah perkembangan pikiran. Pikiran itu sendiri merupakan bagian dari proses yang terjadi dalam otak. Pikiran itu sendiri kegunaannya adalah mengenali, memberi alasan rasional, mengatasi dan memahami kesempatan penting.

Pada hakikatnya inteligensi adalah kemampuan yang dibawa sejak lahir yang memungkinkan seseorang berbuat sesuatu dengan cara tertentu. Stern dalam Monks, Knoers dan Haditono (1999) mendefenisikan inteligiensi sebagai disposisi untuk bertindak, untuk menentukan tujuan-tujuan baru dalam hidup, membuat dan mempergunakan alat untuk mencapai tujuan tertentu.

Kaitan Antara Kreativitas, Inteligiensi dan Keberbakatan 
Dalam penelitiannya, Munandar (1996) dapat membuktikan bahwa hasil studi korelasi dan analisis faktor membuktikan tes kreativitas sebagai dimensi fungsi kognitif yang relative bersatu yang dapat dibedakan dari tes inteligiensi, tetapi berpikir divergen (kreativitas) juga menunjukkan hubungan yang bermakna dengan berpikir konvergen (inteligiensi).

Orang yang kreatif lebih fleksibel dibanding orang yang mempuyai inteligiensi yang baik. Namun inteligiensi yang terakomodasi dengan baik dalam perkembangannya akan melahirkan kreativitas.

Kreativitas itu sendiri merupakan salah satu ciri dari pelaku inteligiensi karena kreativitas juga merupakan manifestasi dari suatu proses kognitif. Dengan demikian, hubungan antara kreativitas dan inteligiensi tidak selalu menunjukkan bukti-bukti yang memuaskan. Walaupun ada yang beranggapan bahwa kreativitas yang rendah pula.Semakin tinggi skor IQ masih terdapat korelasi yang cukup berarti.

Berkenaan dari anak yang berbakat dari Renzulli (1981) tentang keberbakatan dan anak berbakat dapat disimpulkan bahwa yang menentukan keberbakatan seseorang pada hakikatnya dapat dikelompokkan dalam 3 ciriciri yaitu : kemampuan diatas rata-rata, kreativitas dan pengikatan diri (tanggungjawab terhadap tugas). Masing-masing ciri mempuyai peran yang sama-sama menentukan.

Seseorang dapat dikatakan mempuyai bakat intelektual, apabila mempuyai inteligiensi tinggi atau kemampuan diatas rata-rata dalam bidang intelektual, apabila ia mempuyai inteligiensi yang tinggi atau kemampuan diatas rata-rata dalam bidang intelektual yang mempuyai daya abstraksi, kemampuan penalaran dan kemampuan memecahkan masalah. Akan tetapi, kecerdasan yang cukup tinggi belum menjamin keberbakatan seseorang. Kreativitas sebagai kemampuan untuk menciptakan yang baru, sebagai kemampuan untuk menciptakan sesuatu yang baru, sebagai kemampuan juga untuk memberikan gagasan-gagasan yang baru diterapkan.

Dasar Teori Pengembangan Kognitif

Ada 3 pendekatan klasik dalam perkembangan kognitif pada masa usia anak. Pendekatan klasik itu dalam perkembangan kognitif pada masa usia awal :

\section{Pendekatan Behaviouris}

Pendekatan ini mempelajari mekanika dasar pembelajaran.Pendekatan tersebut memberikan perhatian terhadap bagaimana perilaku berubah sebagai respon terhadap sebuah pengalaman.

\section{Pendekatan Psikometris}

Pendekatan ini mencoba mengukur perbedaan kuantitatif dalam kemampuan kognitif dengan menggunakan tes yang mengindikasikan kemampuan.

\section{Pendekatan Piagetian}

Pendekatan ini berhubungan dengan perubahan atau langkah-langkah dalam kualitas fungsi kognitif.Pendekatan ini memberikan bagaimana perhatian dan beradaptasi dengan lingkugannya (Papalia, Old dan Feldman, 2008).

Ketiga pendekatan ini membantu dalam memahami perkembangan kognitif dan diperjelas dengan teori yang mendukung. Dalam rangka mengoptimalkan pengembangan potensi kognitif pada setiap individu, maka para ahli mengemukakan berbagai teori yaitu :

1. Teori ini dikemukakan oleh Charles Spearman. Dia berpendapat bahwa kognisi meliputi kemampuan umum yang diberi kode "g" (general factor) dan kemampuan khusus yang diberi kode "s" (specific factors). Setiap individu pasti memiliki kemampuan ini.

2. Teori Kemampuan Mental Primer (Primary Mental Abilities)

3. Teori ini dikemukakan oleh Thurstone yang berpendapat bahwa kognisi merupakan penjelmaan dari kemampuan primer yaitu kemampuan :

a. Pemahaman bahasa (verbal comprehension)

b. Mengingat (memory)

c. Bernalar (reasoning)

d. Pemahaman ruang (spatial factor)

e. Kemampuan menggunakan bilangan (numerical ability)

f. Kelancaran penggunaan kata-kata (word fluency)

g. Kecepatan memahami (perceptual speed)

h. Teori Kecerdasan jamak (Multiple Inteligences)

Teori ini dikemukakan oleh J P Guilford dan Howard Gardner. Guilford berpendapat bahwa kognisi dapat dilihat tiga kategori dasar atau 
"faces of intellect", yaitu operasi mental, isi (content) dan hasil (product). Menurut Guilford keterkaitan antara ketiga kategori berpikir atau kemampuan intelektual tersebut, telah melahirkan 180 kombinasi kemampuan. Model struktur intelektual Guilford ini mengembangkan wawasan tentang hakikat kognitif dengan menambah factor-faktor seperti "social judgment" (evaluasi terhadap orang lain) dan kreativitas (berpikir "divergen")

1. Teori "Triachic of Intelligence

Teori ini dikemukakan oleh Robert Stenberg. Teori ini juga merupakan pendekatan proses kognitif untuk memahami kognisi. Stenberg mengartikan sebagai suatu "deskripsi tiga bagian kemampuan mental" (proses berpikir mengatasi pengalaman atau masalah baru dan penyesuaian terhadap situasi yang dihadapi yang menunjukan tingkah laku kognitif. Dengan kata lain, tingkah laku itu merupakan produk (hasil) dari penerapan strategi berpikir, mengatasi masalah baru secara kreatif dan cepat. 3 bagian kemampuan mental :

a. Proses mental (berpikir)

Proses mental terdiri dari 3 bagian yaitu :

1. Meta Component

2. Performance Component

3. Knowledge-Acquisition Component

4. Menghadapi pengalaman baru (coping with new experience)

Tingkah laku kognitif dibentuk melalui dua karakteristik yaitu :

b. Menghadapi pengalaman baru (coping with new experience)

Tingkah laku kognitif dibentuk melalui dua karakteristik yaitu :

1. insight $\rightarrow$ kemampuan menghadapi situasi baru

2. automaticity $\rightarrow$ kemampuan berpikir dan memecahkan masalah secara otomatis dan efisien
c. Penyesuaian dengan lingkungan
(adapting to environment) yaitu kemampuan untuk memilih dan beradaptasi dengan tuntutan atau norma lingkungan. Dan biasanya berhubungan dengan memilih karier.

Uji Kolmogorov Smirnov (KS) adalah alat uji statistik yang digunakan untuk menentukan apakah suatu sampel berasal dari suatu populasi yang memiliki sebaran data tertentu atau mengikuti distribusi statistik tertentu.Distribusi statistik yang sering diuji menggunakan uji KS adalah Distribusi Normal (apakah suatu berdistribusi normal).

Uji Kolmogorov Smirnov (KS) didasarkan pada Fungsi Distribusi Empiris (FDE). Jika diberikan $N$ titik data terurutan yaitu $\mathrm{Y}_{-} 1$, Y_2, ..., Y_N $Y 1, Y 2, \ldots, Y N$, maka $\quad$ FDE didefinisikan sebagai

$E N=\mathrm{Ni}$ $\mathrm{N}$

$n i$ adalah jumlah titik yang kurang dari Y_i, Yi, dimana nilai Y_iYi adalah data yang telah diurutkan dari nilai yang terkecil hingga nilai yang terbesar. FDE adalah fungsi yang naik sebesar $1 / \mathrm{N} 1 / N$ pada setiap titik data.

Grafik di bawah ini adalah plot dari FDE dengan Fungsi Distribusi Kumulatif (FDK) Distribusi Normal untuk 100 bilangan acak normal.Garis berwarna hitam adalah FDE dan garis berwarna biru adalah FDK Distribusi Normal.Tes KS didasarkan pada jarak maksimum antara kedua kurva tersebut.Jika FDE mendekati FDK Distribusi Normal artinya sebaran data mengikuti Distribusi Normal.

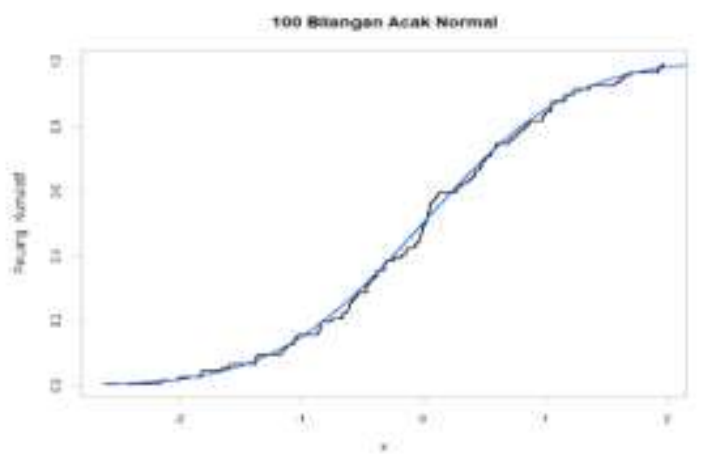

\section{B. Metode Penelitian}

Lokasi Penelitian ini dilaksanakan di SMK Negeri I Berastagi yang berlokasi dijalan SMIK No I Berastagi, Kota Berastagi

Sugiono (2008:117), "populasi adalah wilayah generalisasi yang terdiri atas: objek, subjek, yang mempunyai kualitas dan karakterisitik tertentu yang ditetapkan oleh peneliti untuk dipelajari dan kemudian ditarik kesimpulannya". Adapun populasi dalam penelitian ini adalah semua siswa Kelas X SMK Negeri I Berastagi Tahuna Ajaran 2020/2021.

Adapun jumlah populasi dalam penelitian ini adalah sebayak 3 kelas yakni kelas XKKBT 1, 2 
dan 3 dengan jumlah siswa/i sebanyak 108 orang.

Arikunto (2010:134) yang menyatakan bahwa apabila subyeknya kurang dari 100 lebihbaik diambil semua, sehingga penelitiannya merupakan penelitian populasi. Selanjutnya jika subyeknya besar (lebih dari 100 orang) dapat menggunakan random sampel.Menurutnya sampel di ambil 10\%-15\% hingga 20\%-25\% atau bahkan boleh lebih dari $25 \%$ dari jumlah populasi yang ada. diambil adalah $25 \%$ dari populasi, yakni $25 \% \times 108$ orang $=40,25$ orang, dibulatkan menjadi 40 orang.

Pengambilan sampel dilalukan secara merata ke setiap kelas sehingga setiap responden mempunyai kesempatan yang sama sebagai sampel penelitian.Suatu penelitian diperlukan data melalui pengumpulan data.Data ini kemudian dianalisis untuk sampai pada kesimpulan atau pemecahan masalah yang menjadi akhir penelitian. Analisis tersebut dapat dilakukan dengan langkah-langkah seperti dibawah ini :

1. Uji Validitas Angket

Validitas berarti sejauh mana ketepatan dan kecermatan suatu alat ukur dalam melakukan fungsinya sebagai alat ukur.Uji validitasberarti prosedur pengujian untuk melihat apakah alat ukut yang berupa tes dapat mengukur dengan cermat atau tidak. Instrument dikatakan valid apabila mampu mengukur apa yang diingikan dan dapat mengungkapkan data variabel yang diteliti secara tepat. Tinggi rendahnya validitas instrument menunjukkan sampai sejauh mana data yang dikumpulkan tidak menyimpang darigambaran variabel yang diteliti.

Dalam survei uji validitas dilakukan dengan mengkolerasikan skor setiap item dengan skor total.Teknik kolerasi yang digunakan adalah Pearson Coleration,dimana instrument dikatakan valid apabila nilai koefisiensienan kolerasinya rhitung $>$ rtabel. Syaratminimum untuk dianggap valid adalah $\mathrm{r}=0,3$. Dengan demikian kalau kolerasiantara butirdengan skor total kurang dari 0,3 maka butir dalam instrument tersebut dinyatakan tidak valid.

2. Uji Realibilitas Angket
Untuk mengikuti reliabilitas merupakan indeks yang menunjukkan sejauh mana alat pengukurannya dapat dipercaya atau dapat diandalkan. Instrument dikatakan realibel adalah instrument yang jika digunakan beberapa kali dalam waktu yang berbeda untuk mengukur obyek yang sama akan menghasilkan data yang sama reabilitas data dihitung dengan menggunakan rumus alpha Cronbach dengan kriteria sebagai berikut: $0,00 \mathrm{~s} / \mathrm{d}$ 0,20 tingkat realibilitasnya kurang reliable.,0,20 s/d 0,40 tinkat realibilitasnya agak reliable.,0,40 s/d 0,60 tingkat reliabelitasnya cukup reliable., $0,60 \mathrm{~s} / \mathrm{d}$ 0,80 tingkat reabilitasnya reliable. $0,80 \mathrm{~s} / \mathrm{d}$ 1,00 tingkat realibitassnya sangat reliable.

3. Uji Normalitas

Uji normalitas dilakukan dengan tujuan untuk mengetahui apakah variabel penggangu memiliki distribusi normal sehingga uji $t$ dan uji $f$ dapat dilakukan.Uji normalitas yang digunakan dalam penelitian ini adalah Uji KolmologrovSmirnov.

4. Uji Homogenitas dilakukan dengan tujuan untuk mengetahui apakah variabel berasal dari kelompok yang homengen atau tidak. Uji homogenitas yang digunakan dalam penelitian ini adalah uji liliefors

5. Uji Linearitas

Uji linearitas bertujuan untuk mengetahui apakah dua variabel mempunyai hubungan yang linear atau tidak secara signifikan.Uji ini digunakan sebagai prasyarat dalam analisis korelasi atau regresi linear.Untuk menguji linieritas persamaan regresi sederhana pada variabel penelitian maka dilaksanakan dengan menghitung Fhitung. Uji linieritas regresi digunakan adalah analisis regresi sederhana dengan persamaan regresi $\mathrm{Y}=\mathrm{a}+\mathrm{b} \mathrm{X}$. Untuk menguji keberartian arah regresi (b), maka $\mathrm{F}$ hitung dibandingkan dengan $\mathrm{F}$ tabel. Jika $\mathrm{F}$ hitung > $\mathrm{F}$ tabel maka koefisien arah regresi berarti. Pengujian pada SPSS dengan menggunakan Test for linearity dengan pada taraf signifikan 0,05 .

6. Uji Heteroskedastisitas bertujuan untuk menguji apakah dalam model regeresi terjadi ketidaksamaan variansi dari 
residual satu pengamatan yang lain. Model regeresi maka tidak terjadi heteroskedastisitas.

7. Uji F (Simultan)

Uji $F$ atau simultan digunakan untuk membuktikan kebenaran hipotesis secara simultan atau keseluruhan yaitu untuk mengetahui pengaruh penggunaan internet sebagai sumber belajar dan motivasi belajar secara simultan terhadap prestasi belajar ekonomi yaitu:

Harga tersebut selanjutnya dibandiingkan dengan Ftabeldengan $\mathrm{dk}$ pembilang=k dan $\mathrm{dk}$ penyebut $=(\mathrm{n}-\mathrm{k}-\mathrm{l})$ dengan taraf signifikan $95 \%$ dan $\mathrm{a}=5 \%$ dengan kreteria Fhitung> Ftabel maka hipotesis yang menyatakan ada pengaruh positif namun sebaliknya apabila Fhitung < Ftabel maka hipotesis ditolak.

8. Uji Hipotesis Secara Parsial (Uji t)

Untuk menguji hipotesis pertama dan kedua digunakan analisis korelasi dan regresi sederhana.Sedangkan untuk menguji hipotesis ketiga digunakan analisis korelasi dan regrasi ganda.Selain untuk mengetahui hubugan murni antara $\mathrm{X} 1$ dengan $\mathrm{Y}$ jika $\mathrm{X} 2$ dikontrol dan hubungan murni antara X1 dengan Y Jika $\mathrm{X} 1$ dikontrol digunakan analisis korelasi parsial. Pengujian dilakukan pada taraf signifikan $(\alpha)=0,05$.

\section{Hasil dan Pembahasan}

1. Validitasi Angket

Validitas butir kreativitas mempengaruhi siswa diuji dengan menggunakan bantuan program Spss 12. Secara sederhana butir pernyataan yang baik adalah butir pernyataan yang valid dan reliabel. Untuk menafsirkan harga validitas tiap item dibandingkan dengan harga kritik $\mathrm{r}$ product moment dengan harga $\mathrm{N}=40$ pada taraf signifikansi $\alpha=$ $0,05=0,304$ dengan kriteria jika rhitung $\geq$ dari

2. Uji Reliabilitas Angket

Dari perhitungan diperoleh indeks reliabilitas kuesioner untuk angketpemanfaatan internet sebagai media belajar adalah sebesar 0,914. Indeks ini dikatakan baik apabila mendekati 1 dengan demikian untuk angketpemanfaatan internet sebagai media belajar tergolong sangat tinggi karena mempunyai indeks sebesar 0,914 dan angka ini terletak di antara 0,80 sampai dengan 1,00 .

Indeks reliabilitas kreativitas sebesar 0,920.Indeks ini dikatakan baik apabila mendekati 1, dengan demikian untuk instrumen angket kreativitas mempengaruhi kognitif tergolong sangat tinggi karena mempunyai indeks sebesar 0,920 . Indeks tersebut terletak di antara 0,80 sampai dengan 1,00 .

3. Uji Normalitas

Berdasarkan output Normalitas data dengan Uji Kolmogorov Smirnov dapat di lihat bahwa nilai Kolmogorov Smirnov untuk data pemanfaatan internet sebagai media belajar pada 40 sampel sebesar $=$ 0,607 dengan Probabilitas 0,855 (Asymp.sig. (2-tailed)). Dengan demikian persyaratan data disebut normal karena nilai $\mathrm{P}=0,855>$ dari 0,05 maka datapemanfaatan internet sebagai media belajar pada 40 sampel berdistribusi normal. Berdasarkan output Normalitas data dengan Uji Kolmogorov Smirnov dapat di lihat bahwa nilai Kolmogorov Smirnov untuk data motivasi belajar siswa pada 40 sampel sebesar $=0,444$ dengan Probabilitas 0,989 (Asymp.sig. (2-tailed)). Dengan demikian persyaratan data disebut normal karena nilai $\mathrm{P}=0,989>$ dari 0,05 maka data motivasi belajar pada 40 sampel berdistribusi normal.

4. Uji Homogenitas

Pada output tess of homogeneity of variance angka signifikansi yang ada adalah untuk probabilitas based on mean $=$ 0,495, untuk based on median, 0, 677, probabilitas based on trimmed mean $=$ 0,677 dan probabilitas based trimmed mean 0,503. Oleh karena probabilitas > 0,05; maka dapat diketahui data prestasi belajar memiliki varian yang homogeny dan berasal dari populasi-populasi dengan varians sama.

5. Uji Hipotesis

Proses pengujian dilakukan dengan bantuan SPSS 12.00. Output SPSS 
menunjukkan bahwa Pearson Correlations antara pemanfaatan internet sebagai media belajarterhadap prestasi belajar adalah 0,881 dengan taraf signifikansi 0,000 . Nilai signifikansi ( $\alpha$ ) yang digunakan dalam pengujian ini adalah 0,01 . Signifikansi lebih kecil dari $\alpha$, maka dengan demikian $\mathrm{Ho}$ ditolak dan $\mathrm{Ha}$ diterima. Dengan kata lain terdapat pengaruh yang signifikan kreativitas mempengaruhi kognitif

Proses pengujian dilakukan dengan bantuan SPSS 12.00. Output SPSS menunjukkan bahwa Pearson Correlations antara motivasi belajar terhadap prestasi belajar adalah 0,892 dengan taraf signifikansi 0,000 . Nilai signifikansi ( $\alpha$ ) yang digunakan dalam pengujian ini adalah 0,01 . Signifikansi lebih kecil dari $\alpha$ , maka dengan demikian Ho ditolak dan Ha diterima. Dengan kata lain terdapat pengaruh yang signifikan antara kreativitas mempengaruhi kognitif.

\section{SIMPULAN}

Adapun simpulan yang dapat diambil dari pembahasan yang dilakukan dalam penelitian ini adalah sebagai berikut :

1. Terdapat perkembangan kognitif mempengaruhi siswa secara signifikan hal ini terlihat dari nilai koefisien korelasi yang diperoleh sebesar 0,776 ini menunjukkan bahwa $77,6 \%$ prestasi belajar siswa ditentukan oleh perkembangan kognitif terhadap kreativitas dan sisanya $22,4 \%$ dipengaruhi oleh faktor-faktor lain, koefisien determinasi ini juga signifikan secara statistik yang ditandai dengan nilai signifikansi sebesar 0,00 lebih kecil dari 0,05 atau $\mathrm{F}$ hitung $=131,530>\mathrm{F}$ tabel $=$ 2,054 pengaruh ini bernilai positif artinya kenaikan pada kreativitas mempengaruhi kognitif.

2. Terdapat pengaruh yang signifikan antara perkembangan kognitif hal ini terlihat dari nilai koefisien korelasi yang diperoleh kreativitas terhadap perkembangan kognitif sebesar 0,796 ini menunjukkan bahwa $79,6 \%$ prestasi belajar ditentukan oleh motivasi belajar dan sisanya $20,4 \%$
BIP: Jurnal Bahasa Indonesia Prima Vol. 3, No. 2, 2021, September 2021, PP.

dipengaruhi oleh faktor-faktor lain. Koefisien determinasi ini juga signifikan secara statistik yang ditandai dengan nilai signifikansi sebesar 0,00 lebih kecil dari 0,05 atau Fhitung $=48,461>$ Ftabebel $=$ 2,054 pengaruh ini bernilai positif artinya kenaikan skor kreativitas akan diikuti oleh perkembangan kognitif.

3. Terdapat pengaruh yang signifikan antara kreativitas dengan perkembangan kognitif, dan perkembangan kognitif terhadap kreativitas ini ditunjukkan oleh nilai koefisien pengaruh yang diperoleh adalah sebesar 0,797 ini menunjukkan bahwa $79,7 \%$ perkembangan kognitif sangat mempengaruhi kreatifitas sisanya 23\% dipengaruhi oleh faktor-faktor lain. Berdasarkan nilai B konstanta dan nilai B perkembangan kognitif mempengaruhi kreatifitas dan B maka persamaan regresi ganda yang dapat dibentuk yaitu $\mathrm{Y}=\mathrm{a}+$ b1 $11+$ b2x2 = 49,264+0,422X1+1,955X2. Adapun dasar pengambilan keputusannya untuk mengetahui pengaruh masingmasing adalah sebagai berikut: Berdasarkan nilai thitung $>$ ttabel untuk kreatifitas, dengan $(n=40)$ dan $\mathrm{k}=$ jumlah variabel (3) sehingga $\mathrm{db}=40-3=37$. ttabel dengan $\mathrm{db}=3$ pada taraf kepercayaan $95 \%$ dengan $(\alpha 0,05 / 2=$ $0,025)=2,052$. thitung $\mathrm{X} 1=2,06>$ ttabel $=$ 2,042. Berdasarkan nilai thitung $>$ ttabel untuk perkembangan mempengaruhi kreatifitas diperoleh nilai ttabel dengan $\mathrm{db}$ $=39$ pada taraf kepercayaan $95 \%$ dengan ( $\alpha 0,05 / 2=0,025)=2,042$. thitung X2 $=20,620>$ ttabel $=2,042$. Dengan demikian dapat disimpulkan bahwa kteativitas sangat berpengaruh terhadap perkembangan kognitif siswa kelas XKKBT 1-3 tahun 2020/2021 terbukti meyakinkan berdasarkan taraf kepercayaan $95 \%$.

\section{Daftar Pustaka}

Arikunto, Suharsimi. 2006.Prosedur Penulisan Suatu Pendekatan Praktek. Jakarta: Rineka Cipta. Arsyad, Azhar. 2007. Media Pembelajaran. Jakarta: PT. Raja Grafindo Persada 
BIP: Jurnal Bahasa Indonesia Prima Vol. 3, No. 2, 2021, September 2021, PP.

Asmani, Jamal. 2011.Tips Elefektifitas Pemanfaatan Teknologi Informasi dan Komunikasi dalam Dunia Pendidikan. Yogyakarta : Diva Press

Engineering Statistics Handbook. (2009). Kolmogorov-Smirnov Goodness-of-Fit Test. USA: NIST Sematech Sudjana. (1996). Metoda Statistika. Bandung: “TARSITO” Bandung

Aunurahman 2009.Belajar dan Pembelajaran Alfabeta

Campbell, David 2017. Mengembangkan kreativitas diterjemahkan oleh A.M.Mangunhardjana Yogyakarta : PT Karisius
Hajar, Pamadhi 2012.Pendidikan Seni Konsep Habitus dan Kurikulum Pendidikan Seni di Sekolah Yogyakarta: UNY Press

Munandar U.1992. Mengembangkan bakat dan kreativitas anak sekolah: Petunjuk Bagi Para Guru dan Orangtua. Jakarta PT Gramedia

Rochman Natawidjaya dan Moein Moesa 1992.Psikologi Pendidikan Jakarta ; Depdikbud

Sunarto 2016.Konsep Seni dalam Estetika Ekspresivisme Yogyakarta PT KanisiusEstetika dalam "Konteks Pendidikan Seni" Jurnal Refleksi Edukatika, 7 (2); 102-1 